\title{
Improving Zinc Recovery from Steelmaking Dust by Switching from Conventional Heating to Microwave Heating
}

\author{
Mamdouh Omran ${ }^{1,2}\left(\mathbb{D} \cdot\right.$ Timo Fabritius $^{1} \cdot$ Yaowei Yu ${ }^{2} \cdot$ Eetu-Pekka Heikkinen ${ }^{1} \cdot$ Guo Chen $^{3} \cdot$ Yilmaz Kacar $^{4}$
}

Received: 4 July 2020 / Accepted: 23 November 2020 / Published online: 21 December 2020

(c) The Author(s) 2020

\begin{abstract}
Recently, microwave energy has attracted increasing interest for accelerating thermal reactions. This study investigated the impact of microwave heating on the zinc recovery rate from electric arc furnace (EAF) and chromium converter (CRC) dusts. The results indicated that microwave heating required a lower temperature to recover zinc from EAF and CRC dusts compared with that in conventional thermal heating. For CRC dust, zinc recovery rates of $37.84 \%$ and $97.43 \%$ were obtained with conventional and microwave heating, respectively, at $850{ }^{\circ} \mathrm{C}$. For EAF dust, zinc recovery rates of $79.88 \%$ and $98.20 \%$ were obtained with conventional and microwave heating, respectively, at $850{ }^{\circ} \mathrm{C}$. The improved zinc recovery in this study was concluded to results from the rapidity of microwave heating and the interactions between the electromagnetic microwave field and the molecules of heated materials.
\end{abstract}

The contributing editor for this article was Hojong Kim.

Supplementary Information The online version of this article (https://doi.org/10.1007/s40831-020-00319-x) contains

supplementary material, which is available to authorized users.

Mamdouh Omran

mamdouh.omran@oulu.fi

$\triangle$ Yaowei Yu

yaoweiyu@shu.edu.cn

$\bowtie$ Guo Chen

guochen@kust.edu.cn

1 Process Metallurgy Research Group, Faculty of Technology, University of Oulu, Oulu, Finland

2 State Key Laboratory of Advanced Special Steel, School of Materials Science and Engineering, Shanghai University, Shanghai, China

3 Kunming Key Laboratory of Energy Materials Chemistry, Yunnan Minzu University, Kunming, China

4 Material Science and Engineering Department, Carnegie Mellon University, Pittsburgh, USA 


\section{Graphical Abstract}

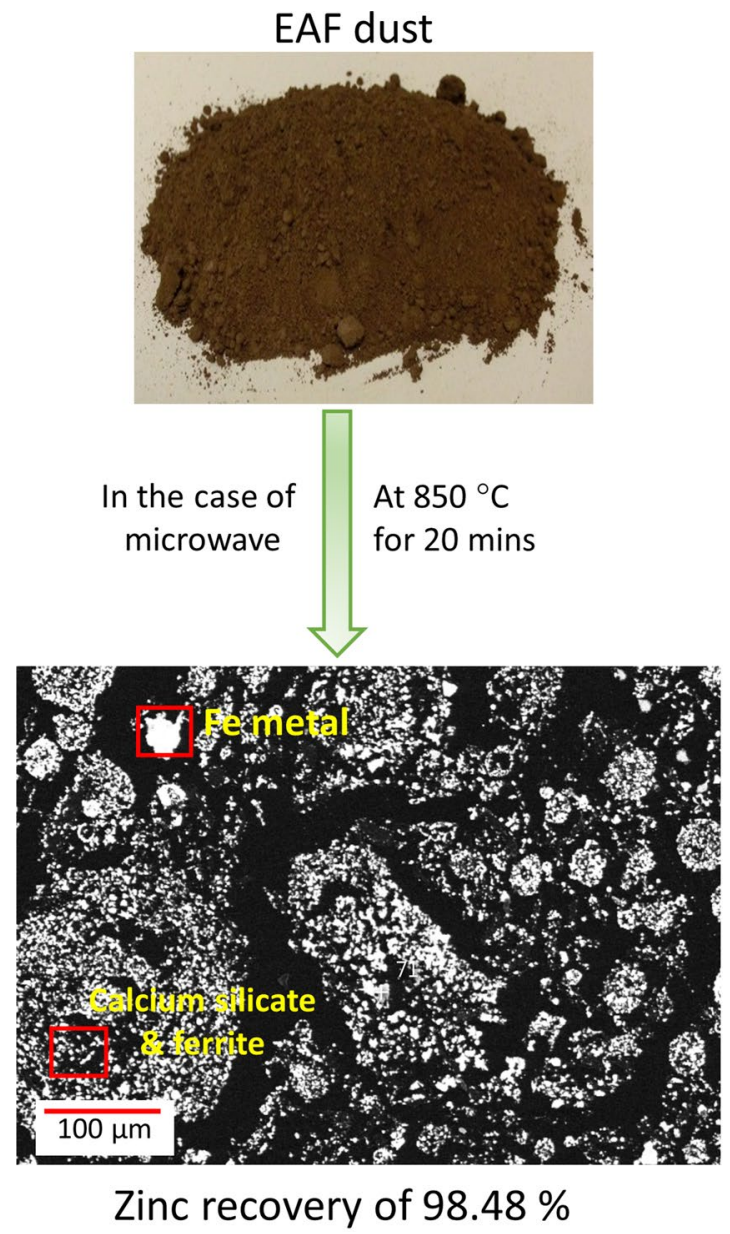

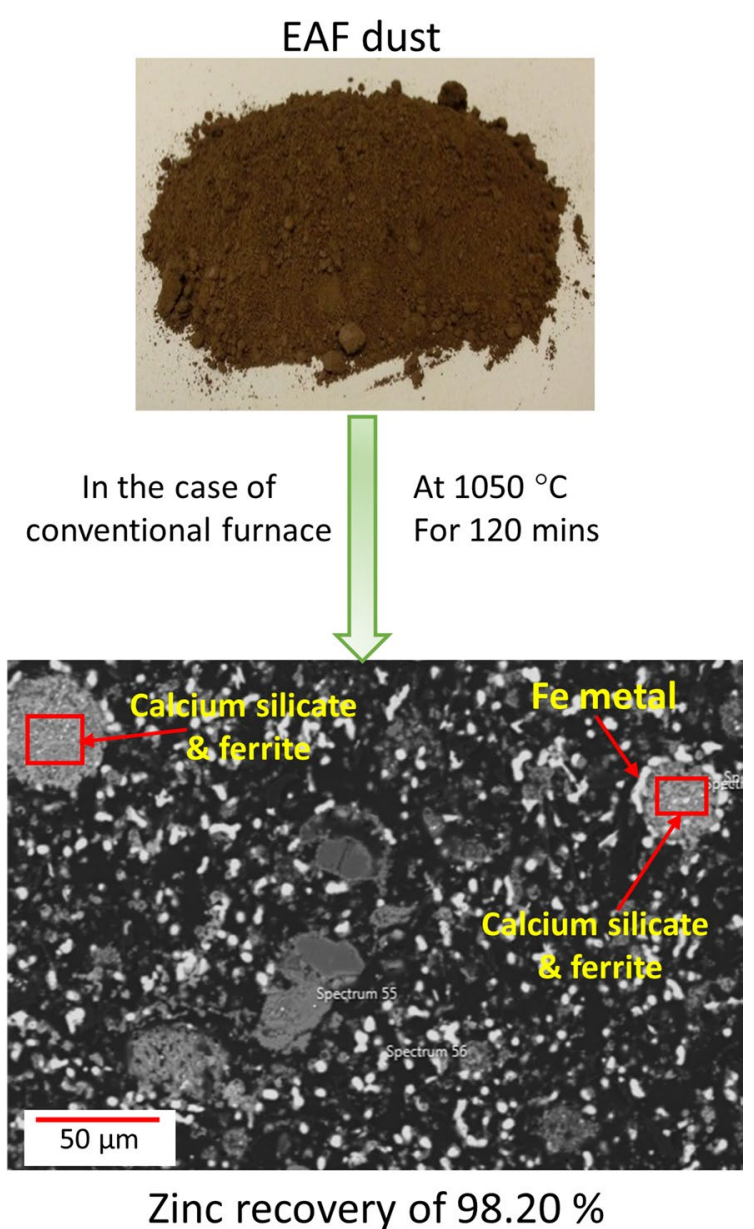

Zinc recovery of $98.20 \%$

Keywords Microwave heating - Zinc recovery $\cdot$ Electric arc furnace (EAF) dust $\cdot$ Chromium converter (CRC) dust

\section{Introduction}

Recently, microwave energy has attracted increasing interest in the field of metallurgy to improve the recovery of valuable metals from raw materials and secondary wastes. Microwave energy is a type of electromagnetic wave with frequencies ranging from $300 \mathrm{MHz}$ to $300 \mathrm{GHz}[1,2]$. Microwave heating is produced by the interaction between the dielectric material and the microwave field [3, 4]. By contrast, in conventional thermal heating, a sample is heated from the outside to the inside through heat transfer mechanisms [5, 6]. Recent studies have reported a significant enhancement in reaction rates when using microwave heating instead of conventional thermal heating [7, 8]. For example, Hunt et al. [7] found that microwave-induced heating influences the thermodynamics of a reaction; specifically, it accelerates a reaction by reducing the activation energy.
Pyrometallurgical and hydrometallurgical processes are commonly used for zinc recovery from steelmaking dusts [9, 10]. Steelmaking wastes are fine-grained materials comprising metal oxides $(\mathrm{Fe}, \mathrm{Cr}, \mathrm{Zn})$ that can be recycled back into the steelmaking cycle. The main phases in such dusts are zincite $(\mathrm{ZnO})$ and franklinite $(\mathrm{Zn}, \mathrm{Fe}) \mathrm{Fe}_{2} \mathrm{O}_{4}$ [11], and the presence of zinc causes operational problems that hinder the direct recycling of steelmaking wastes in the steelmaking cycle. To solve these problems, a pyrometallurgical method has been proposed for zinc recovery from steelmaking dusts through the reduction and evaporation of zinc [12]. The Waelz kiln method is the principal pyrometallurgical process used for treating steelmaking dust. This method involves the carbothermic reduction of zinc phases and the volatilization of metallic zinc [9, 12]. However, it suffers from disadvantages such as high energy requirements, environmental pollution, and requirement of a gas system to treat the evaporated dusts and gases [9]. Hydrometallurgical methods are 
based on the chemical leaching of zinc phases contained in steelmaking dusts. However, they suffer from disadvantages such as the difficulty of leaching zinc ferrite and the undesirable dissolution of iron [13].

In light of these problems, microwave energy has attracted increasing interest as a means for recycling steelmaking dusts while protecting the environment. Vereš et al. [14] applied microwave-assisted leaching for zinc removal from steelmaking dusts. Omran and Fabritius [9] found that microwave heating is a promising and effective technology for zinc removal from steelmaking dusts [14-16]. Microwave absorption ability tests indicated that steelmaking wastes are good microwave-absorbing materials [17]. Lee [18] and Nishioka et al. [19] applied microwaves to electric arc furnace (EAF) dust and successfully recovered metallic zinc. These studies showed that microwaves were effective for processing steelmaking wastes.

The abovementioned studies showed that microwaves could effectively recover zinc from wastes; however, they did not compare the zinc recovery results of microwave heating to those of conventional thermal heating. The present study aims to reuse and recycle steelmaking by-products and to reduce the use of primary raw materials by using microwave heating. Specifically, it examines the effect of microwave radiation on zinc recovery from steelmaking dusts. The zinc recovered from chromium converter (CRC) and EAF dusts using microwave heating was compared with that recovered using conventional thermal heating.

\section{Experimental}

\section{Preparation of Materials and Pellets}

CRC and EAF carbon steel dust were obtained from Outokumpu Tornio and Ovako Imatra Steel Plants in Finland, respectively.

Table 1 lists the chemical compositions of CRC and EAF dusts. EAF dust mainly contains zinc and iron in the form of franklinite $\left(\mathrm{ZnFe}_{2} \mathrm{O}_{4}\right)$ and zincite $(\mathrm{ZnO})$; further, its $\mathrm{ZnO}$ and $\mathrm{Fe}_{2} \mathrm{O}_{3}$ contents were $34.45 \mathrm{wt} \%$ and $45.64 \mathrm{wt} \%$, respectively. CRC dust mainly contains zinc, iron, and chromium oxides with chromite $\left(\mathrm{FeCr}_{2} \mathrm{O}_{4}\right)$ and zincite $(\mathrm{ZnO})$ main phases; further, its $\mathrm{ZnO}, \mathrm{Fe}_{2} \mathrm{O}_{3}$, and $\mathrm{Cr}_{2} \mathrm{O}_{3}$ contents were
$19.08 \mathrm{wt} \%, 20.83 \mathrm{wt} \%$, and $22.89 \mathrm{wt} \%$, respectively. In addition to $\mathrm{Fe}, \mathrm{Zn}$, and $\mathrm{Cr}$, EAF and CRC dusts also contain $\mathrm{Ca}$, $\mathrm{Si}, \mathrm{Mg}$, and Mn (Table 1).

After drying the samples, the CRC and EAF dusts were mixed homogenously with graphite using a gate mortar. The percentage of graphite was 1.2 times the stoichiometric quantity of carbon needed to reduce both zincite and zinc ferrite into elemental zinc and iron. Approximately $0.5 \%$ of bentonite was added to the mixture as a binder. Around $3 \mathrm{~g}$ of the sample was compressed at $150 \mathrm{~kg} \mathrm{f} \mathrm{cm}^{-2}$ for $60 \mathrm{~s}$ by using a hydraulic oil press.

\section{Experimental}

\section{Microwave Furnace}

Figure 1 shows the experimental setup of the microwave furnace. The microwave source consisted of two magnetrons with $1.1 \mathrm{~kW}$ power and a $2.45 \mathrm{GHz}$ frequency. The

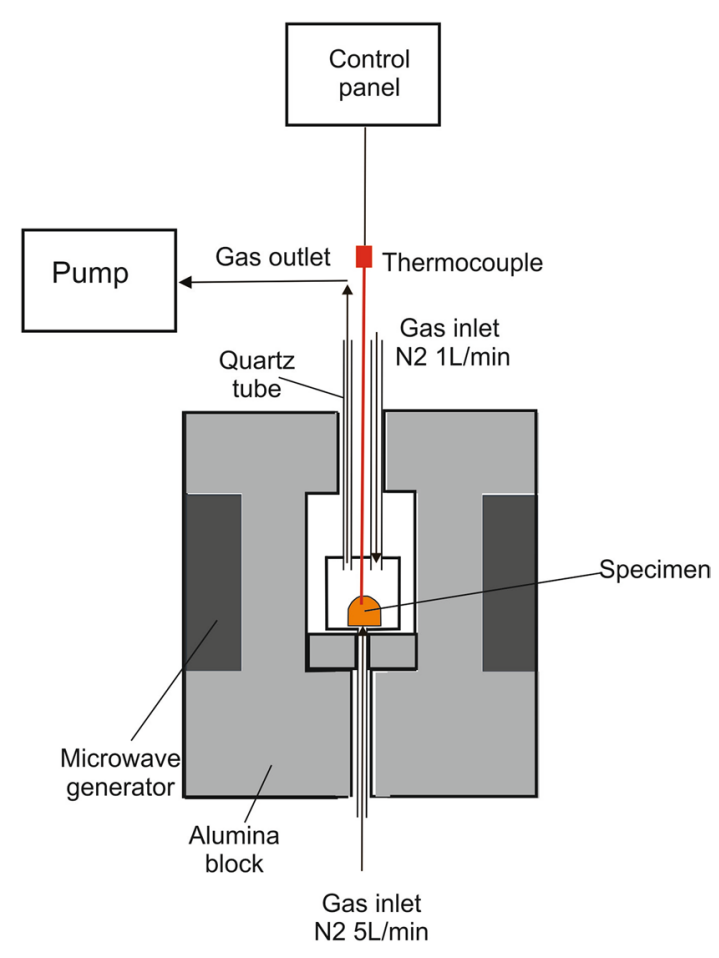

Fig. 1 Experimental setup for microwave heating

Table 1 Compositions of CRC and EAF dusts considered in the calculations

\begin{tabular}{|c|c|c|c|c|c|c|c|c|c|c|c|c|c|}
\hline \multirow[t]{2}{*}{ Material } & \multicolumn{9}{|c|}{ Chemical compositions of the dusts (wt $\%$ ) } & \multicolumn{4}{|c|}{$\begin{array}{l}\text { Initial amounts of dusts in the calculations } \\
(\mathrm{g})\end{array}$} \\
\hline & $\mathrm{C}$ & $\mathrm{Fe}_{2} \mathrm{O}_{3}$ & $\mathrm{ZnO}$ & $\mathrm{Cr}_{2} \mathrm{O}_{3}$ & $\mathrm{CaO}$ & $\mathrm{MgO}$ & $\mathrm{MnO}$ & $\mathrm{SiO}_{2}$ & $\mathrm{~K}_{2} \mathrm{O}$ & EAF dust & CRC dust & $\mathrm{C} \%$ & $\mathrm{Zn} \%$ \\
\hline EAF dust & 1.54 & 34.45 & 45.64 & 0.60 & 6.08 & 1.10 & 4.09 & 3.21 & 3.29 & 100 & - & 11.80 & 36.67 \\
\hline CRC dust & 0.31 & 20.83 & 19.08 & 22.89 & 14.72 & 10.06 & 1.04 & 10.30 & 0.76 & - & 100 & 5.13 & 15.33 \\
\hline
\end{tabular}


temperature was detected using a thermocouple. This thermocouple was linked to a setting panel that controlled the temperature throughout the experiments. The experiments were performed at 650,750 , and $850{ }^{\circ} \mathrm{C}$ for $20 \mathrm{~min}$. The sample was placed in an alumina crucible. $\mathrm{N}_{2}$ gas was flowed over the sample from the top and bottom with flow rates of 1 and $5 \mathrm{~L} \mathrm{~min}^{-1}$, respectively. The evaporated zinc vapor from the sample was pulled by a pump into a collector. The weight loss of the sample was recorded every $60 \mathrm{~s}$. The sample was left to cool down in the microwave furnace after the experiment. Then, the sample was prepared for chemical and mineralogical analyses.

\section{Conventional Furnace}

Figure 2 shows the experimental setup of the conventional furnace. A thermocouple was used to measure the temperature. The experiments were performed at 850,950 , and $1050{ }^{\circ} \mathrm{C}$ for $2 \mathrm{~h}$. The sample was placed in a basket and then placed into the furnace through a platinum wire at room temperature and heated to the chosen experimental temperature with a heating rate of $10^{\circ} \mathrm{C} \mathrm{min}^{-1}$. The sample wire was connected to a digital mass loss recording software that measured the weight loss during the experiments. $\mathrm{N}_{2}$ gas was flowed over the sample from the top and bottom with flow rates of 1 and $5 \mathrm{~L} \mathrm{~min}^{-1}$, respectively. The output

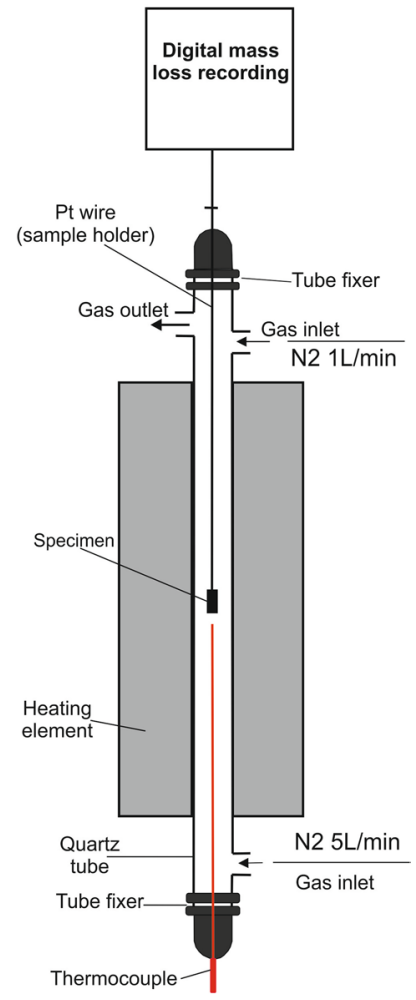

Fig. 2 Experimental setup for conventional thermal heating vapors and gases from the furnace were cooled and condensed with water. After the experiment, the sample was left to cool down in the furnace in the $\mathrm{N}_{2}$ atmosphere. Then, the sample was prepared for chemical and mineralogical analyses.

\section{Characterization Methods}

The chemical composition of the CRC and EAF dusts was determined using an X-ray fluorescence (XRF) spectrometer (Model Bruker AXS S4 Pioneer XRF). The XRF source was a Rh-tube with a maximum power of $4 \mathrm{~kW}$. The carbon content was measured using a LECO carbon analyzer. The mineralogical composition of the dusts was identified using a Rigaku SmartLab 9 kW XRD. Measurements were performed using a cobalt tube with Co K $\alpha$ radiation operated at $40 \mathrm{kV}$ voltage and a $135 \mathrm{~mA}(5.4 \mathrm{~kW})$ rotating anode. A Zeiss ULTRA plus field-emission scanning electron microscope was used to examine the micromorphology of the dust.

A Netzsch STA 409 PC Luxx was used to investigate the thermal behavior of the dusts. The thermal behavior was studied in $\mathrm{N}_{2}$ atmosphere from 20 to $1300{ }^{\circ} \mathrm{C}$ with a heating rate of $10^{\circ} \mathrm{C} \mathrm{min}^{-1}$. For the experiments, $30.84 \mathrm{mg}$ of the dusts was packed in a platinum crucible.

\section{Thermodynamic Calculations}

FactSage (version 7.2) and its FactPS, FToxid, and FSstel databases were used for the thermodynamic calculations. Table 1 lists the compositions and the initial amounts of the dusts for the calculations. The calculations were performed for $100 \mathrm{~g}$ of dust at a total pressure of $1 \mathrm{~atm}$, whereas the initial amount of carbon was calculated separately for each case. These calculations were performed to estimate the occurrence of zinc in different phases as a function of temperature. The quantity of carbon was chosen to be 1.2 times the percentage required to reduce the zinc and iron to an elemental form through the following reactions:

$\mathrm{ZnO}_{(\mathrm{s})}+\mathrm{C}_{(\mathrm{s})}=\mathrm{Zn}_{(\mathrm{g})}+\mathrm{CO}_{(\mathrm{g})}$,

$\mathrm{ZnFe}_{2} \mathrm{O}_{4(\mathrm{~s})}+4 \mathrm{C}_{(\mathrm{s})}=\mathrm{Zn}_{(\mathrm{g})}+2 \mathrm{Fe}_{(\mathrm{s})}+4 \mathrm{CO}_{(\mathrm{g})}$,

$\mathrm{Fe}_{2} \mathrm{O}_{3(\mathrm{~s})}+3 \mathrm{C}_{(\mathrm{s})}=2 \mathrm{Fe}_{(\mathrm{s})}+3 \mathrm{CO}_{(\mathrm{g})}$.

Figure 3 shows the standard Gibbs free energies for these three reactions. Zinc oxide and zinc ferrite spontaneously reduce to zinc at $950{ }^{\circ} \mathrm{C}$ and $800{ }^{\circ} \mathrm{C}$, respectively. On the other hand, hematite spontaneously reduced to iron at $650{ }^{\circ} \mathrm{C}$.

Figure 4 shows the equilibrium distributions of zinc in the different phases of the thermodynamic calculations. These 
Fig. 3 Standard Gibbs free energies for Eqs. (1)-(3)

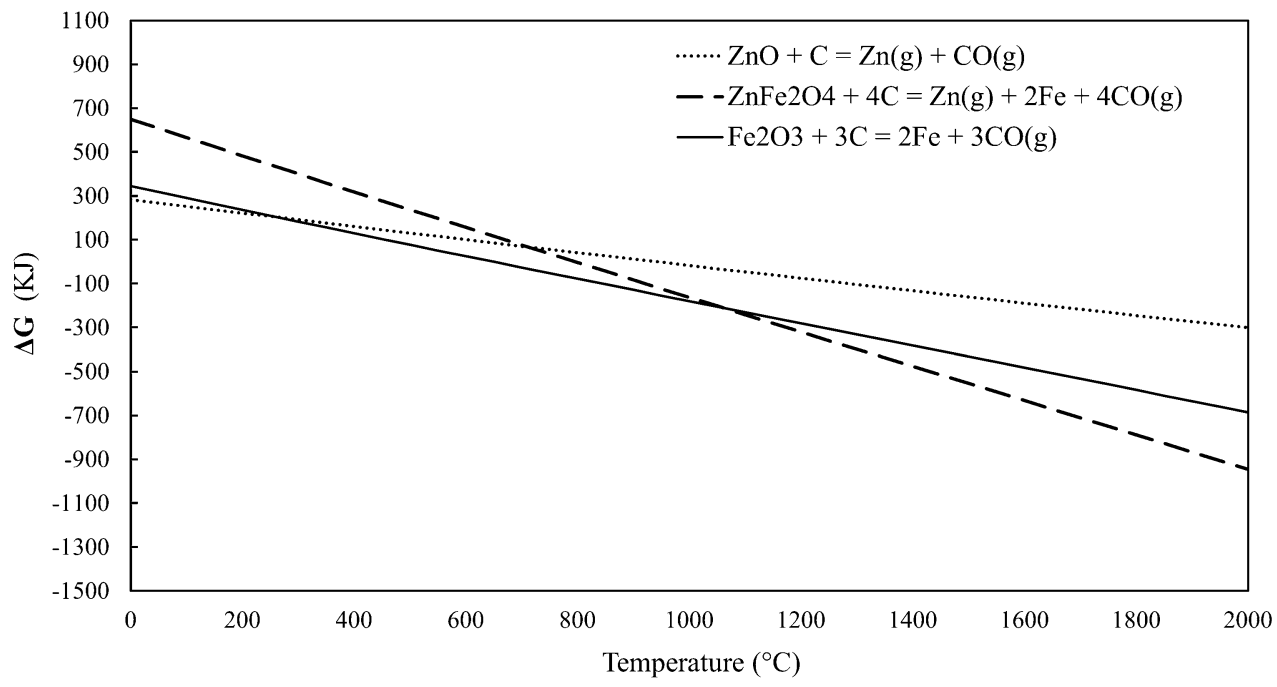

diagrams provide an idea of how much zinc can theoretically be reduced in different cases and at different temperatures. Relative amounts (percentages) were used to perform comparisons between different calculations, even though the initial amounts of zinc were different in each calculation.

Figure 4 shows that the reduction of zinc from EAF and CRC dusts is more complicated than that from pure zincite and zinc ferrite owing to the other components present in these systems. Solid solutions with spinel and monoxide structures are thermodynamically assumed to be formed in the system, and the reduction of zinc existing in these phases is more difficult owing to the lower activity and higher stability of $\mathrm{ZnO}$ in comparison to those of pure stoichiometric compounds.

Figure $4 \mathrm{a}$ shows that when reducing EAF dust with carbon, zinc in the solid monoxide phase is expected to form. According to the calculations, higher temperatures of $\sim 1200{ }^{\circ} \mathrm{C}$ are required to ensure the "complete" removal of zinc from the EAF dust to the gas phase. For CRC dust (Fig. 4b), the situation is even more complicated, with the occurrence of a zinc-containing spinel phase in equilibrium even at high temperatures. Owing to the high stability of the spinel phase, according to our calculations, higher temperatures of up to $1300{ }^{\circ} \mathrm{C}$ are needed to remove all the zinc.

However, it should be noted that Fig. 4 represents a situation in equilibrium. Therefore, the reduction and removal of zinc from the zinc-monoxide and zinc-containing spinel phases would require high temperatures if these phases existed in the original material. If it does not, it is possible that it does not have enough time to form during heating despite its high thermodynamic stability. In this case, zinc would mainly exist in phases from which it is more easily reduced, and lower temperatures than those presented in Fig. 4 could be sufficient for its reduction and removal. For instance, in the original CRC dust, zinc was not present in its spinel form. Therefore, zinc in the spinel phase was not expected to form during the heating process.

\section{Results and Discussion}

\section{Thermal Behavior of CRC and EAF Dusts}

Figure 5 shows differential scanning calorimetry-thermogravimetry (DSC-TG) curves of the CRC and EAF dusts with 1.2 times the stoichiometric amount of the reducing agent. For CRC dust, the DSC curve exhibited two main reactions at $955-1100{ }^{\circ} \mathrm{C}$ and $1222-1297^{\circ} \mathrm{C}$ (Fig. 5a). The reduction of $\mathrm{ZnO}$ initiated at $955^{\circ} \mathrm{C}$. Zinc was completely reduced at a temperature of $\sim 1100{ }^{\circ} \mathrm{C}[9,20]$. Calcium ferrites formed at high temperatures of $1222-1297{ }^{\circ} \mathrm{C}$ [20]. The TG curve shows the two stages of weight loss for these two reactions. For EAF dust, DSC curves show two main reactions occurring at $807-865^{\circ} \mathrm{C}$ and $925-951{ }^{\circ} \mathrm{C}$ owing to the reduction of zinc-containing phases into zinc vapor [9]. First, $\mathrm{ZnFe}_{2} \mathrm{O}_{4}$ reduces to $\mathrm{ZnO}$ and $\mathrm{Fe}_{2} \mathrm{O}_{3}$ at $807-895{ }^{\circ} \mathrm{C}$; then, $\mathrm{ZnO}$ reduces at $925-1000{ }^{\circ} \mathrm{C}$. $\mathrm{TG}$ weight loss within this temperature range is related to $\mathrm{ZnFe}_{2} \mathrm{O}_{4}$ decomposition and zinc evaporation (Fig. 5a).

\section{Interaction of CRC and EAF Dusts with Microwave Energy}

The dielectric properties of $\mathrm{CRC}$ and $\mathrm{EAF}$ have been studied in detail previously [17]. At temperatures of 20-600 ${ }^{\circ} \mathrm{C}$, the changes in the dielectric constant $\left(\varepsilon^{\prime}\right)$ and loss factor $\left(\varepsilon^{\prime \prime}\right)$ of CRC and EAF dusts were insignificant. When the temperature exceeded $600{ }^{\circ} \mathrm{C}$, the $\varepsilon^{\prime}$ and $\varepsilon^{\prime \prime}$ values of the dusts increased (Fig. S1, Supplementary Material). 


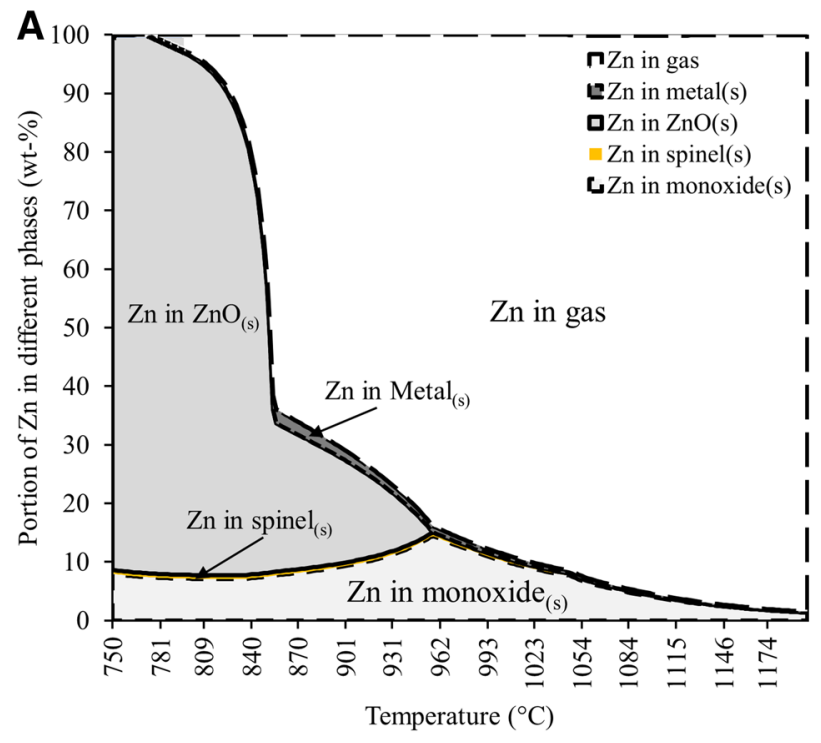

B

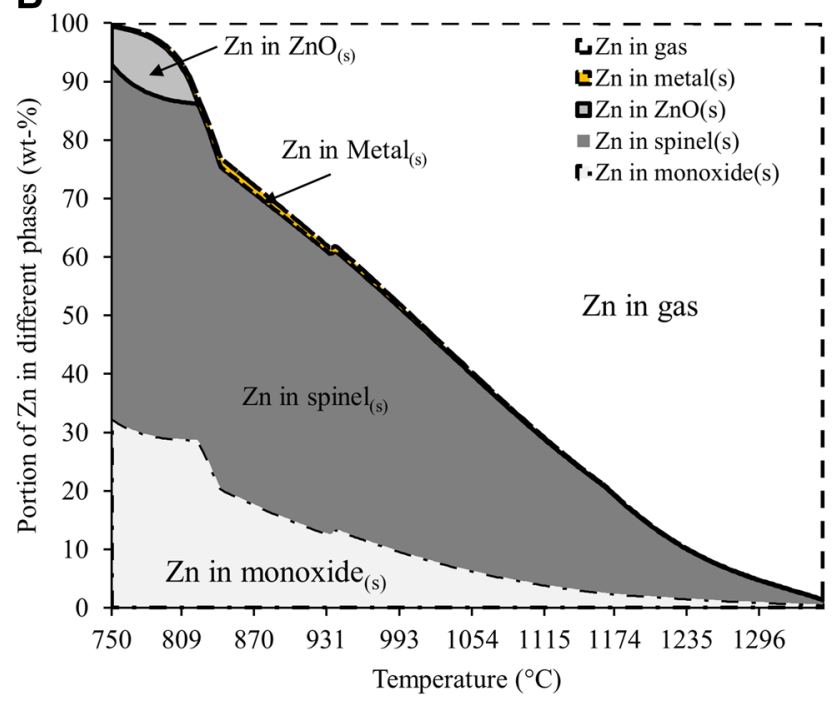

Fig. 4 Portion of zinc in different phases of thermodynamic equilibrium as a function of temperature when a CRC dust and b EAF dust are heated with carbon

Omran et al. [17] stated that the changes in the $\varepsilon^{\prime}$ and $\varepsilon^{\prime \prime}$ values of CRC and EAF dusts matched the spectra curves of the $\mathrm{CO} / \mathrm{CO}_{2}$ gases released from the dusts at $622-645{ }^{\circ} \mathrm{C}$. Yonglin et al. [21] stated that phase decomposition resulted in a change in the electrical and ionic conductivities.

Figure 6 shows the temperature profiles of the CRC and EAF dusts at a microwave power of $1.1 \mathrm{~kW}$. Initially, the temperature increases rapidly owing to phase decomposition and $\mathrm{CO} / \mathrm{CO}_{2}$ release [22]. Figure 6 shows that the microwave heating of the dusts improved after adding graphite to the dusts. The temperature of the CRC and EAF dusts increased from 578 and $639^{\circ} \mathrm{C}$ to 1022 and $1044{ }^{\circ} \mathrm{C}$, respectively, after $210 \mathrm{~s}$ of microwave heating.
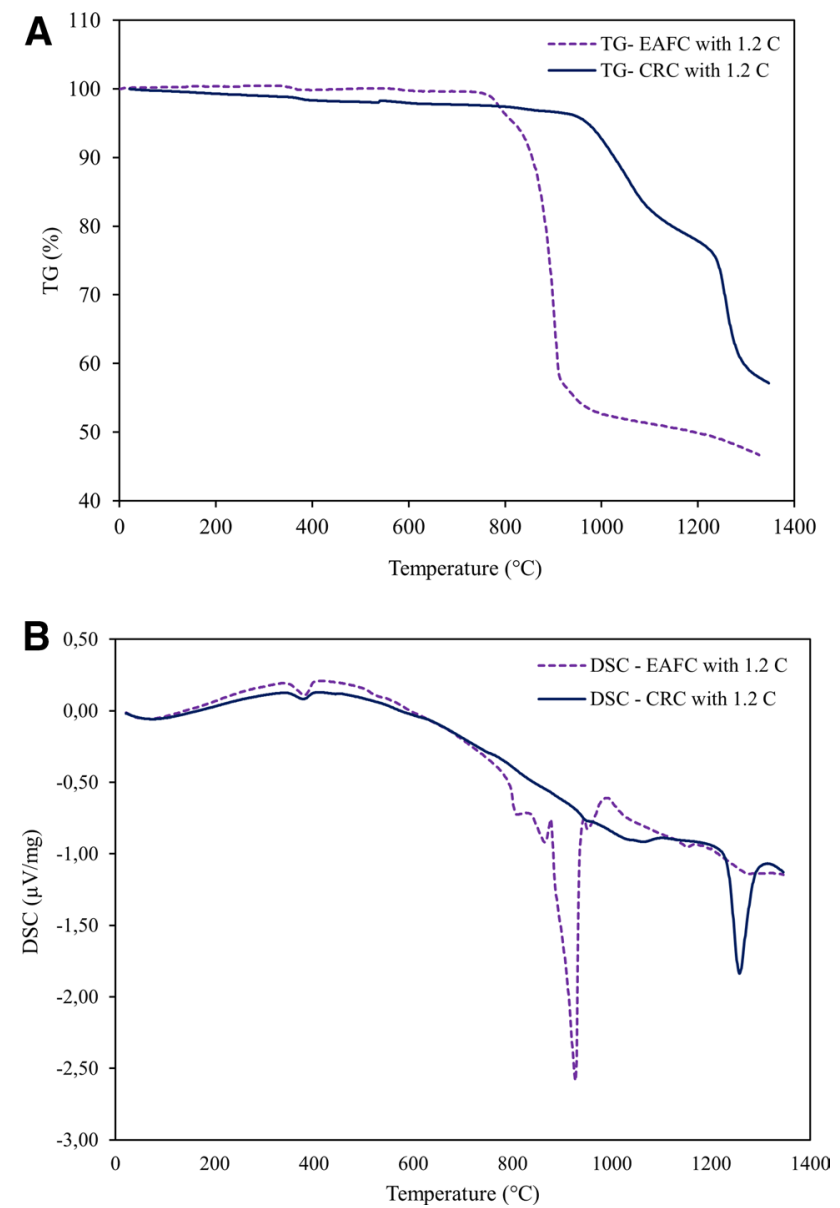

Fig. 5 Thermal analyses of CRC and EAF dusts: a TG and b DSC

\section{Zinc Recovery from CRC and EAF Dusts}

For comparison, zinc recovery experiments were performed using both microwave and conventional furnaces under similar conditions.

\section{Measurement of Weight Loss During Experiments}

Figure 7 shows the weight loss of the CRC dust in microwave and conventional heating experiments. Similar weight loss patterns were observed in both experiments. With microwave heating, rapid weight loss was seen in the early stages of the experiment, following which the mass became constant. With conventional thermal heating, rapid weight loss was seen in the early stages, following which the rate decreased gradually. The total weight loss of CRC dusts at $1050{ }^{\circ} \mathrm{C}$ with conventional heating was $28.45 \mathrm{wt} \%$; this was consistent with the thermogravimetric analysis result for this temperature. With microwave heating, the weight loss at $850{ }^{\circ} \mathrm{C}$ was $25.48 \mathrm{wt} \%$.

Figure 8 shows the weight loss of the EAF dust in microwave and conventional heating experiments. In both 
Fig. 6 Microwave heating profile of CRC and EAF dusts at a microwave power of $1.1 \mathrm{~kW}$

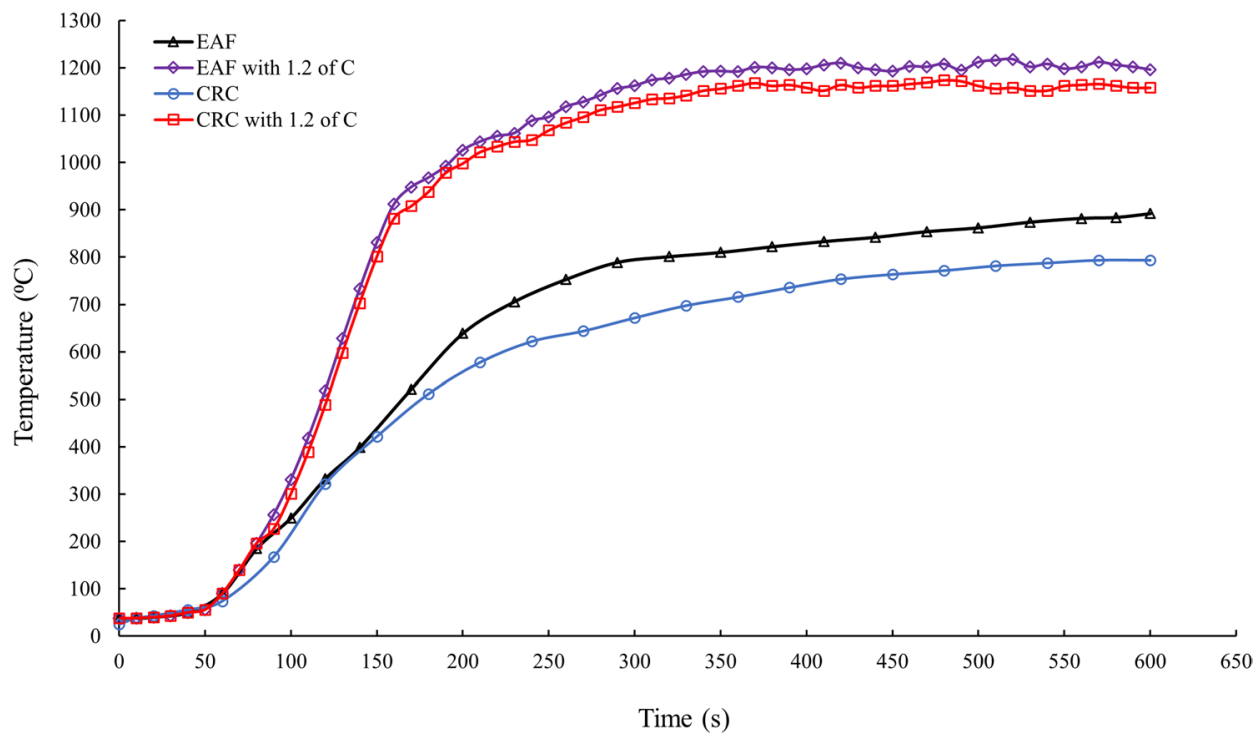

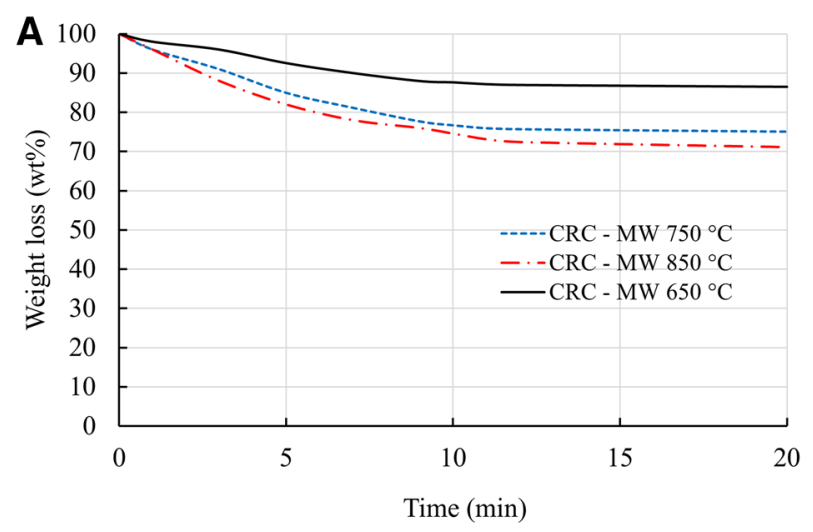

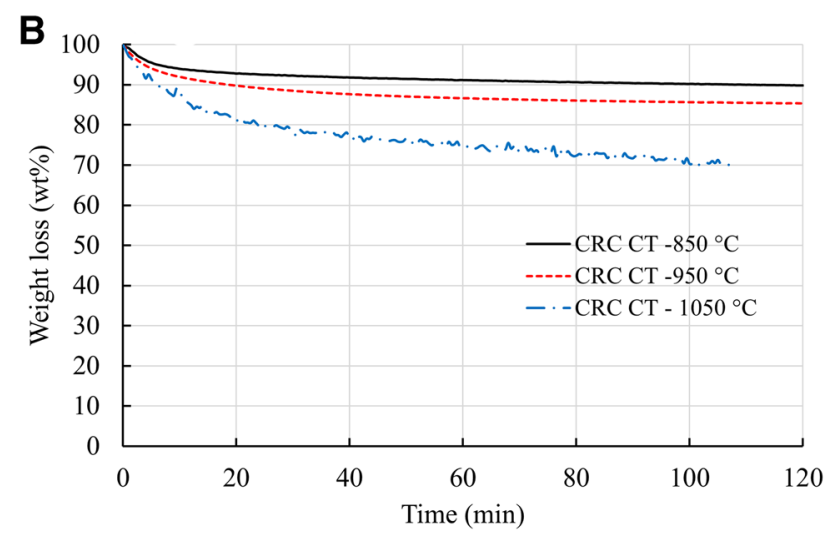

Fig. 7 Experimental mass loss for CRC dust: a microwave heating and $\mathbf{b}$ conventional thermal heating

experiments, rapid weight loss was seen in the very early stages of the reactions; however, after $\sim 10 \mathrm{~min}$, the mass became constant. These findings indicated that almost
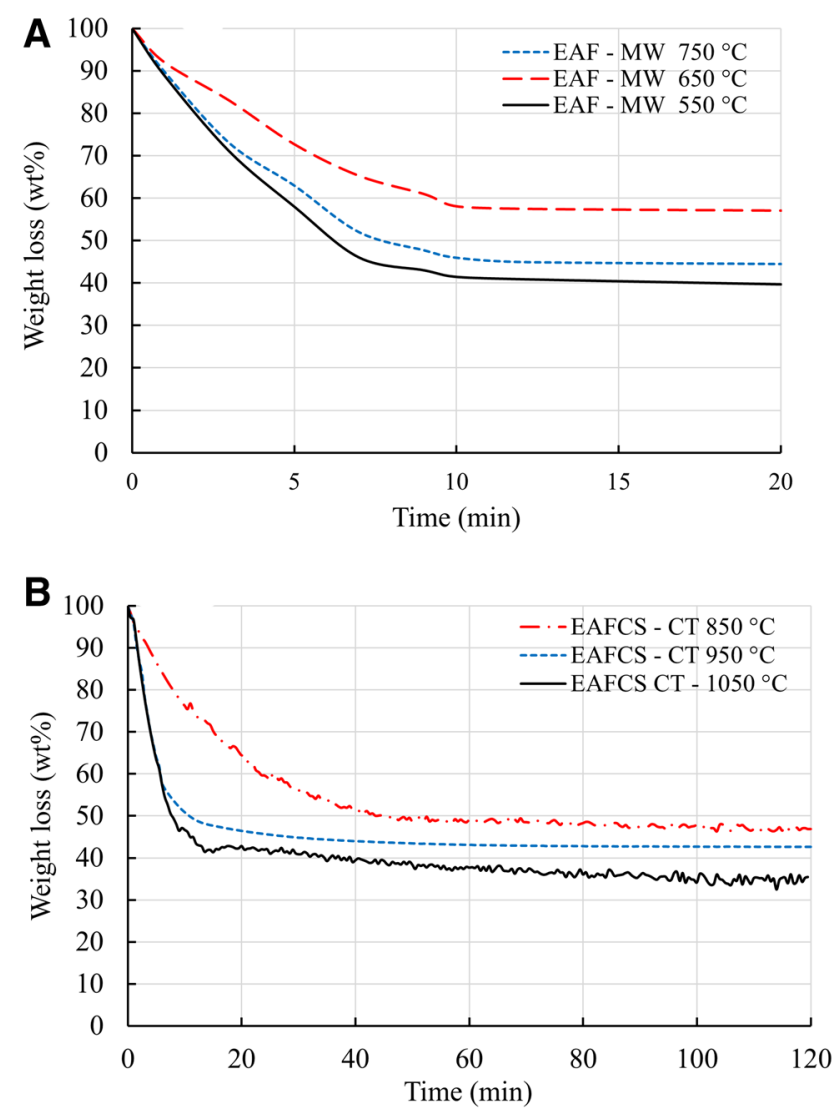

Fig. 8 Experimental mass loss for EAF dust: a microwave heating and $\mathbf{b}$ conventional thermal heating

all zinc was removed from the dust in the early stage of the experiments. The weight loss of the EAF dust with 
conventional heating at $1050{ }^{\circ} \mathrm{C}$ was $62.73 \mathrm{wt} \%$, whereas that with microwave heating at $850{ }^{\circ} \mathrm{C}$ was $59.22 \mathrm{wt} \%$.

\section{Comparison of Zinc Recovery Between Microwave and Conventional Heating}

Table 2 lists the chemical compositions of the CRC dust and the zinc recovery rate after microwave and conventional heating experiments. In conventional heating experiments, the zinc recovery rate was $37.84 \%, 77.46 \%$, and $98.47 \%$ at 850,950 , and $1050{ }^{\circ} \mathrm{C}$, respectively. In microwave heating experiments, the zinc recovery rate was $39.47 \%, 75.73 \%$, and $97.43 \%$ at 650,750 , and $850{ }^{\circ} \mathrm{C}$, respectively. The highest zinc recovery rates were $98.47 \%$ with conventional heating at $1050{ }^{\circ} \mathrm{C}$ and $97.43 \%$ with microwave heating at $850{ }^{\circ} \mathrm{C}$ (Fig. 9a). The difference between the reaction temperatures required to obtain the same zinc recovery rate was $\sim 200^{\circ} \mathrm{C}$. The residues were found to be rich in $\mathrm{Cr}$ and $\mathrm{Fe}$ as well as $\mathrm{Si}$ and $\mathrm{Ca}$.

The XRD patterns of CRC dust show that the $\mathrm{ZnO}$ phase reduced with increases in temperature in both microwave and conventional heating experiments (Fig. 10a). For conventional heating at $1050{ }^{\circ} \mathrm{C}$ and microwave heating at $850{ }^{\circ} \mathrm{C}$, $\mathrm{XRD}$ indicated that the $\mathrm{ZnO}$ phase was completely removed from CRC dust. Chromite and calcium silicate phases were seen in the residues. Figure 11 shows SEM images of the products obtained with conventional heating at $1050{ }^{\circ} \mathrm{C}$ and microwave heating at $850^{\circ} \mathrm{C}$. These images show spheroids of chromite enclosed by $\mathrm{Ca}-\mathrm{Mg}$ silicates phases (Fig. 11). Energy-dispersive X-ray spectroscopy (EDX) analyses indicated that no zinc-bearing phases (zincite and franklinite) were detected in the residues.

Table 3 lists the chemical compositions of EAF and zinc recovery after the microwave and conventional heating experiments. With conventional heating, zinc recovery rates of $79.88 \%, 86.83 \%$, and $98.40 \%$ were obtained at 850 , 950 , and $1050{ }^{\circ} \mathrm{C}$, respectively. With microwave heating, zinc recovery rates of $61.19 \%, 79.29 \%$, and $98.20 \%$ were obtained at 650,750 , and $850{ }^{\circ} \mathrm{C}$, respectively (Fig. 9b). The highest zinc recovery rates were $\sim 98 \%$ with conventional heating at $1050{ }^{\circ} \mathrm{C}$ and microwave heating at $850{ }^{\circ} \mathrm{C}$. As in the results for CRC dusts, the same zinc recovery rate could be obtained under microwave heating at a reaction temperature that was lower by $\sim 200^{\circ} \mathrm{C}$. The EAF residues were rich in $\mathrm{Fe}(\sim 58 \mathrm{wt} \%)$ as well as $\mathrm{Si}$ and $\mathrm{Ca}$.

The XRD patterns show that $\mathrm{ZnO}$ and $\mathrm{ZnFe}_{2} \mathrm{O}_{4}$ peaks nearly vanished in the samples with conventional heating at $1050{ }^{\circ} \mathrm{C}$ and microwave heating at $850{ }^{\circ} \mathrm{C}$ (Fig. 10b). Figure 12 shows SEM images of the residue with conventional and microwave heating at $1050{ }^{\circ} \mathrm{C}$ and $850^{\circ} \mathrm{C}$, respectively. SEM images show that the residue was mostly composed of an agglomeration of calcium ferrite and calcium silicate
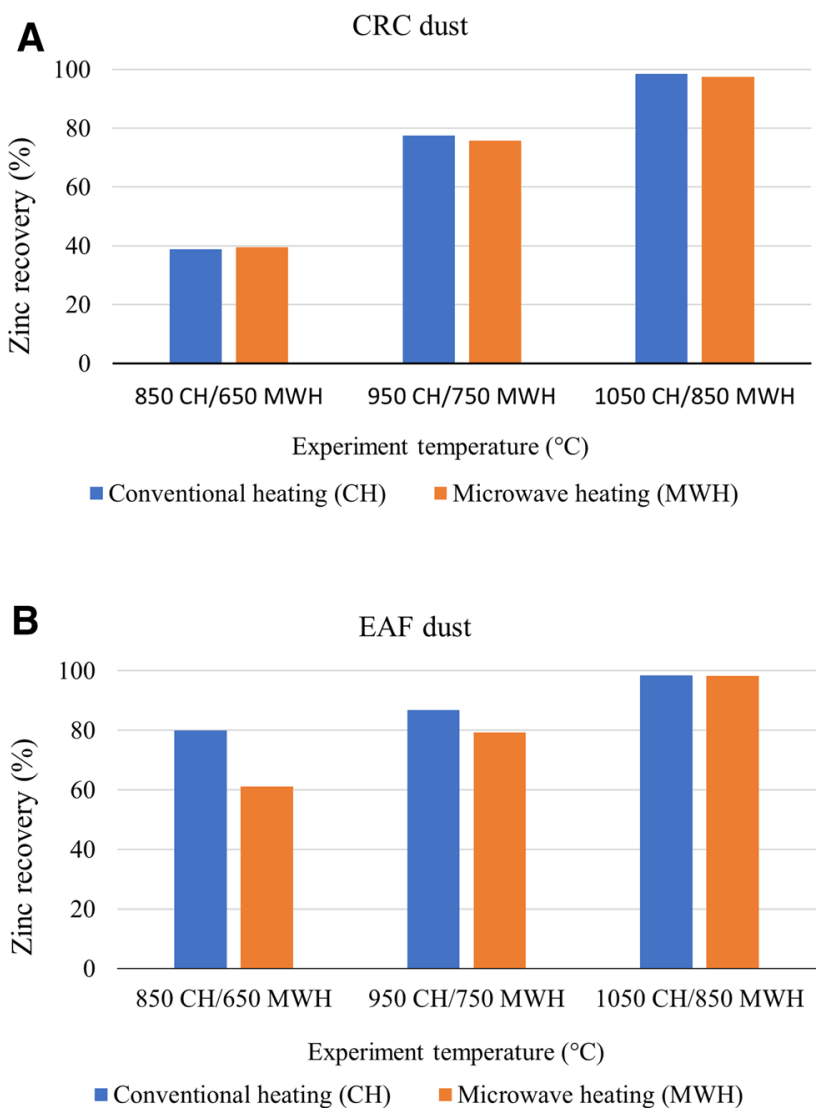

Fig. 9 Comparison of zinc recovery rates at different temperatures: a CRC dust and $\mathbf{b}$ EAF dust
Table 2 Main elements of CRC residues

\begin{tabular}{lrrrrrrrl}
\hline Experiment temperature $\left({ }^{\circ} \mathrm{C}\right)$ & $\mathrm{ZnO}$ & $\mathrm{Fe}_{2} \mathrm{O}_{3}$ & $\mathrm{Cr}_{2} \mathrm{O}_{3}$ & $\mathrm{MgO}$ & $\mathrm{SiO}_{2}$ & $\mathrm{CaO}$ & $\mathrm{MnO}$ & $\mathrm{Zn}$ removal (\%) \\
\hline $\begin{array}{l}\text { Conventional furnace experiments } \\
850\end{array}$ & 11.86 & 27.41 & 31.38 & 7.03 & 8.01 & 10.70 & 1.32 & 37.84 \\
950 & 4.30 & 29.17 & 33.33 & 7.73 & 9.90 & 11.66 & 1.20 & 77.46 \\
1050 & 0.29 & 30.56 & 33.80 & 8.59 & 11.43 & 12.41 & 1.20 & 98.47 \\
Microwave furnace experiments & & & & & & & & \\
650 & 11.53 & 26.56 & 30.49 & 6.88 & 9.43 & 9.89 & 1.26 & 39.47 \\
750 & 4.63 & 28.72 & 32.87 & 7.59 & 10.21 & 11.53 & 1.29 & 75.73 \\
850 & 0.49 & 30.32 & 33.19 & 7.78 & 11.13 & 11.95 & 1.11 & 97.43 \\
\hline
\end{tabular}


Fig. 10 XRD patterns of steelmaking dusts: a CRC dust and $\mathbf{b}$ EAF dust
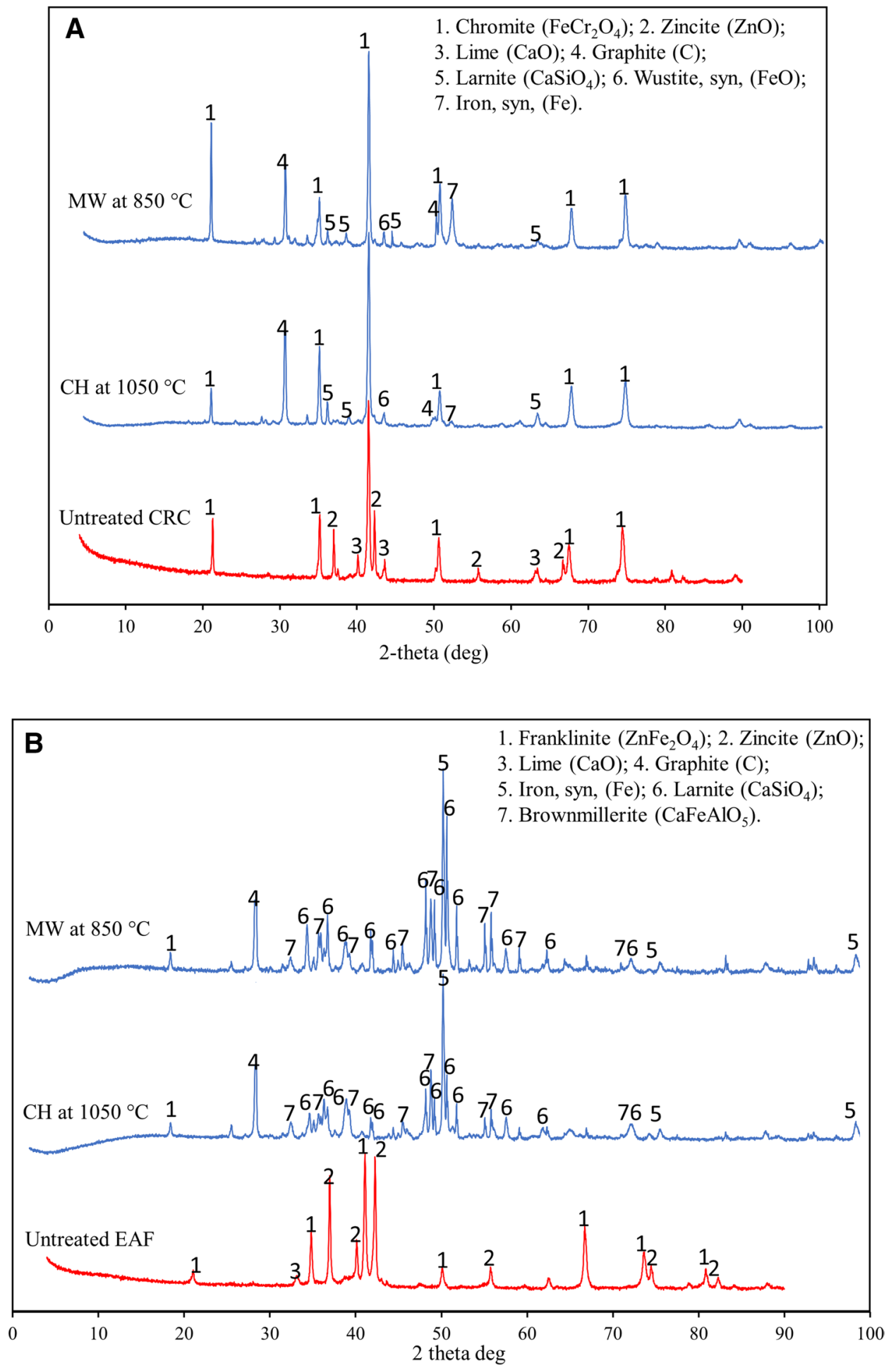

along with iron. The morphology of the particles was different: with microwave heating, the particles were agglomerated, which is a property of microwave heating.

The results indicated that the zinc-containing spinel phases and zinc in the monoxide phase do not form during the reduction process, as predicated by the thermodynamic calculations. Almost all zinc could be removed from CRC and EAF dusts with microwave heating at lower temperatures than those in conventional thermal heating, as discussed above. Previous studies [7, 23, 24] have already reported improvements 

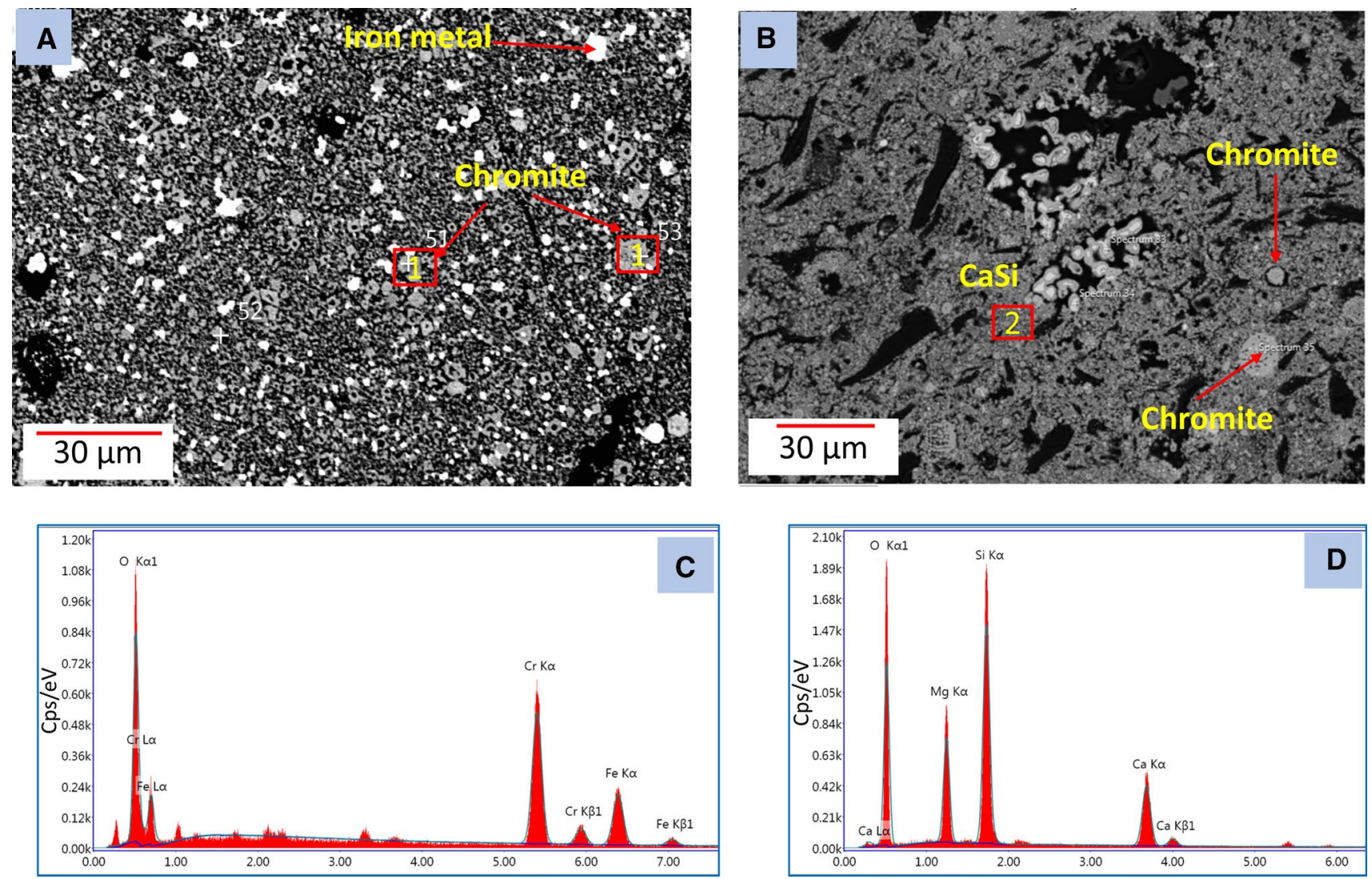

Fig. 11 SEM images of CRC dust: a microwave heating at $850{ }^{\circ} \mathrm{C}$ and $\mathbf{b}$ conventional thermal heating at $1050{ }^{\circ} \mathrm{C}$. $\mathbf{c}$ and $\mathbf{d}$ EDX analyses of $(1$, 2) in $\mathbf{a}$ and $\mathbf{b}$, respectively

Table 3 Main elements of EAF residues

\begin{tabular}{lccccccccc}
\hline Experiment temperature $\left({ }^{\circ} \mathrm{C}\right)$ & $\mathrm{ZnO}$ & $\mathrm{Fe}_{2} \mathrm{O}_{3}$ & $\mathrm{Cr}_{2} \mathrm{O}_{3}$ & $\mathrm{MgO}$ & $\mathrm{Al}_{2} \mathrm{O}_{3}$ & $\mathrm{SiO}_{2}$ & $\mathrm{CaO}$ & $\mathrm{MnO}$ & $\mathrm{Zn} \mathrm{removal}(\%)$ \\
\hline $\begin{array}{l}\text { Conventional furnace experiments } \\
850\end{array}$ & 9.18 & 54.53 & 1.17 & 3.85 & 1.86 & 7.33 & 14.80 & 4.12 & 79.88 \\
950 & 6.01 & 56.64 & 1.17 & 4.60 & 2.16 & 8.12 & 15.55 & 3.06 & 86.83 \\
1050 & 0.73 & 60.76 & 1.11 & 4.80 & 2.01 & 8.42 & 15.60 & 3.05 & 98.40 \\
Microwave furnace experiments & & & & & & & & \\
650 & 17.71 & 52.22 & 0.81 & 3.04 & 1.10 & 6.34 & 13.77 & 3.64 & 61.19 \\
750 & 9.45 & 55.96 & 0.922 & 3.05 & 1.35 & 7.55 & 15.18 & 3.06 & 79.29 \\
850 & 0.83 & 60.45 & 1.08 & 3.59 & 1.64 & 8.60 & 16.34 & 3.04 & 98.20 \\
\hline
\end{tabular}

in the zinc recovery rate with microwave heating owing to the rapid nature of microwave heating in addition to the interactions between the electromagnetic field of the microwaves and the heated molecules [7, 23, 24]. Zhou et al. [8] found that microwave energy improves the reaction rate through the direct reduction of the activation energy required to activate the reactant molecules. However, a more detailed analysis of these mechanisms is needed to completely explain these phenomena.

\section{Conclusions}

This study investigates the effect of microwave radiation on the zinc recovery rate from CRC and EAF dusts and compares it with those achieved in conventional thermal heating. The results indicated that nearly all zinc could be recovered from CRC and EAF dusts with microwave heating at lower 

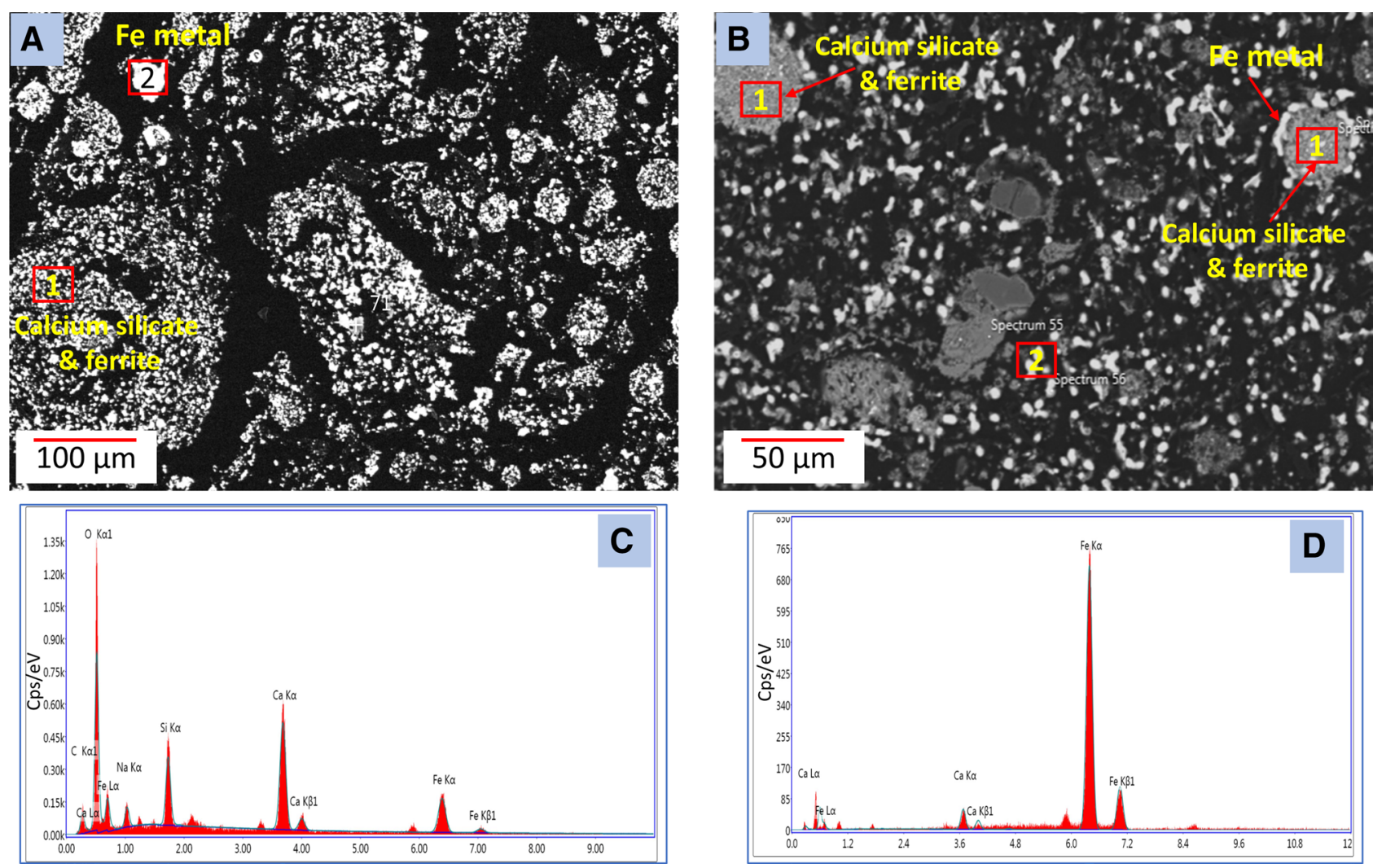

Fig. 12 SEM images of EAF dust: a microwave heating at $850{ }^{\circ} \mathrm{C}$ and $\mathbf{b}$ conventional thermal heating at $1050{ }^{\circ} \mathrm{C}$. $\mathbf{c}$ and $\mathbf{d}$ EDX analyses of $(1$, 2) in $\mathbf{a}$ and $\mathbf{b}$, respectively

temperatures (by $\sim 200{ }^{\circ} \mathrm{C}$ ) than those in conventional thermal heating.

For CRC dusts, zinc recovery rates of $37.84 \%$ and $97.43 \%$ were obtained in conventional and microwave heating experiments, respectively, at $850^{\circ} \mathrm{C}$. For EAF dusts, zinc recovery rates of $79.88 \%$ and $98.20 \%$ were obtained in conventional and microwave heating experiments, respectively, at $850^{\circ} \mathrm{C}$. Although microwave heating is a promising and effective technique for zinc recovery from steelmaking dusts, scaling it up to an industrial scale remains challenging. Fundamentals studies on the microwave cavity design and dielectric properties of treated materials are required to understand the engineering challenges of scaling up microwave heating.

Acknowledgements This work was funded by Business Finland under Research Program (SYMMET). The authors thank Professor Chris Pistorius from the Material Science and Engineering Department, Carnegie Mellon University, for offering us the use of laboratory facilities and helping us in conducting a part of this work at Carnegie Mellon University.

Funding Open access funding was provided by University of Oulu including Oulu University Hospital.

\section{Compliance with Ethical Standards}

Conflict of interest All authors declare that they have no conflicts of interest.

Open Access This article is licensed under a Creative Commons Attribution 4.0 International License, which permits use, sharing, adaptation, distribution and reproduction in any medium or format, as long as you give appropriate credit to the original author(s) and the source, provide a link to the Creative Commons licence, and indicate if changes were made. The images or other third party material in this article are included in the article's Creative Commons licence, unless indicated otherwise in a credit line to the material. If material is not included in the article's Creative Commons licence and your intended use is not permitted by statutory regulation or exceeds the permitted use, you will need to obtain permission directly from the copyright holder. To view a copy of this licence, visit http://creativecommons.org/licenses/by/4.0/.

\section{References}

1. Li K, Chen G, Li X, Peng J, Ruan R, Omran M, Chen J (2019) High-temperature dielectric properties and pyrolysis reduction characteristics of different biomass-pyrolusite mixtures in microwave field. Bioresour Technol 294:122217 
2. Li K, Chen J, Peng J, Ruan R, Omran M, Chen G (2020) Dielectric properties and thermal behavior of electrolytic manganese anode mud in microwave field. J Hazard Mater 384:121227

3. Chen G, Li L, Tao CY, Liu ZH, Chen N, Peng JH (2016) Effects of microwave heating on microstructures and structure properties of the manganese ore. J Alloys Compd 657:515-518

4. Ye XL, Guo SH, Qu WW, Yang L, Hu T, Xu SM, Zhang LB, Liu BG, Zhang ZM (2019) Microwave field: high temperature dielectric properties and heating characteristics of waste hydrodesulfurization catalysts. J Hazard Mater 366:432-438

5. Jones DA, Lelyveld TP, Mavrofidis SD, Kingman SW, Miles NJ (2002) Microwave heating applications in environmental engineering-a review. Resour Conserv Recycl 34:75-90

6. Omran M, Fabritius T, Mattila R (2015) Thermally assisted liberation of high phosphorus oolitic iron ore: a comparison between microwave and conventional furnaces. Powder Technol 269:7-14

7. Hunt J, Ferrari A, Lita A, Crosswhite M, Ashley B, Stiegman AE (2013) Microwave-specific enhancement of the carbon-carbon dioxide (Boudouard) reaction. J Phys Chem C 117:26871-26880

8. Zhou J, Xu W, You Z, Wang Z, Luo Y, Gao L, Yin Ch, Peng R, Lan L (2016) A new type of power energy for accelerating chemical reactions: the nature of a microwave-driving force for accelerating chemical reactions. Sci Rep 6:25149

9. Omran M, Fabritius T (2019) Utilization of blast furnace sludge for the removal of zinc from steelmaking dusts using microwave heating. Sep Purif Technol 210:867-884

10. Oustadakis P, Tsakiridis PE, Katsiapi A, Agatzini-Leonardou S (2010) Hydrometallurgical process for zinc recovery from electric arc furnace dust (EAFD) Part I: characterization and leaching by diluted sulphuric acid. J Hazard Mater 179:1-7

11. Omran M, Fabritius T (2017a) Effect of steelmaking dust characteristics on suitable recycling process determining: ferrochrome converter (CRC) and electric arc furnace (EAF) dusts. Powder Technol 308:47-60

12. Al-Harahsheh M, Kingman S, Al-Makhadmah L, Hamilton IE (2014) Microwave treatment of electric arc furnace dust with PVC: dielectric characterization and pyrolysis-leaching. J Hazard Mater 274:87-97

13. Vereš J, Lovás M, Jakabský Š, Šepelák V, Hredzák S (2012) Characterization of blast furnace sludge and removal of zinc by microwave assisted extraction. Hydrometallurgy 129-130:67-73

14. Omran M, Fabritius T, Heikkinen E-P (2019) Selective zinc removal from electric arc furnace (EAF) dust by using microwave heating. J Sustain Metall 5:331-340
15. Omran M, Fabritius T (2018) Improved removal of zinc from blast furnace sludge by particle size separation and microwave heating. Miner Eng 127:265-276

16. Omran M, Fabritius T (2017b) Treatment of blast furnace sludge (BFS) using a microwave heating technique. Ironmak Steelmak 44(8):619-629

17. Omran M, Fabritius T, Chen G, He A (2019) Microwave absorption properties of steelmaking dusts: effects of temperature on the dielectric constant $\left(\varepsilon^{\prime}\right)$ and loss factor $\left(\varepsilon^{\prime \prime}\right)$ at $1064 \mathrm{MHz}$ and 2423 MHz. RSC Adv 9:6859-6870

18. Lee $\mathbf{J}$ (2008) Metal recovery from industrial wastes by microwave heating. In: Proceeding of 3rd international conference on process development in iron and steelmaking, Lulea, June 2008. MEFOS, Lulea, pp 547-550. ISBN 978-91-633-2269-3

19. Nishioka K, Maeda T, Shimizu M (2002) Dezincing behavior from iron and steelmaking dusts by microwave heating. ISIJ Int 42:S19-S22

20. Pickles CA (2008) Thermodynamic analysis of the selective carbothermic reduction of electric arc furnace dust. J Hazard Mater 150:265-278

21. Yonglin J, Bingguo L, Peng L, Jinhui P, Libo Z (2017) Dielectric properties and oxidation roasting of molybdenite concentrate by using microwave energy at $2.45 \mathrm{GHz}$ frequency. Metall Mater Trans B 48B:3047-3057

22. Lovas M, Kovacova M, Dimitrakis G, Čuvanova S, Znamenaćkova I, Jakabsky Š (2010) Modeling of microwave heating of andesite and minerals. Int J Heat Mass Transf 53:3387-3393

23. Xu W, Zhou J, Li H, Yang P, You Z, Luo Y (2014) Microwaveassisted catalytic reduction of $\mathrm{NO}$ into $\mathrm{N}_{2}$ by activated carbon supported $\mathrm{Mn}_{2} \mathrm{O}_{3}$ at low temperature under $\mathrm{O}_{2}$ excess. Fuel Process Technol 27:1-6

24. Xu W, Zhou J, Ou Y, Luo Y, You Z (2015) Microwave selective effect: a new approach towards oxygen inhibition removal for highly effective NO decomposition by microwave catalysis over $\mathrm{BaMn}_{\mathrm{x}} \mathrm{Mg}_{1-\mathrm{x}} \mathrm{O}_{3}$ mixed oxides at low temperature under excess oxygen. Chem Commun 51:4073-4076

Publisher's Note Springer Nature remains neutral with regard to jurisdictional claims in published maps and institutional affiliations. 